\title{
Social support of families with tracheostomized children
}

\author{
Apoio social de famílias de crianças traqueostomizadas \\ Apoyo social de familias de niños traqueostomizados
}

\section{Hellen Joyce Moreira de Lemos' ORCID: 0000-0002-8043-3740}

Ana Márcia Chiaradia Mendes-Castillo' ORCID: 0000-0002-0367-1606

' Universidade Estadual de Campinas. Campinas, São Paulo, Brazil.

How to cite this article: Lemos HJM, Mendes-Castillo AMC. Social support of families with tracheostomized children. Rev Bras Enferm. 2019;72(Suppl 3):282-9. doi: http://dx.doi.org/10.1590/0034-7167-2018-0708

Corresponding Author:

Hellen Joyce Moreira de Lemos E-mail: hellenjoyce2008@hotmail.com

Submission: 09-03-2018 Approval: 03-02-2019

\begin{abstract}
Objective: To understand the social support of families with tracheostomized children. Method: Qualitative study using the Model of Dimensions of Social Support together with the Family System-Illness model as theoretical frameworks, based on the hybrid model of thematic analysis. Nine families with tracheostomized children were interviewed in an outpatient pediatric otorhinolaryngology department of a public hospital in the inner state of São Paulo. Results: The experience of social support to each phase of the family experience was presented in three themes: "Knowing the need for a tracheostomy", "Performing a tracheostomy" and "Living with a tracheostomy". Final considerations: Understanding how the experience of social support occurs can support assessment and intervention strategies, aiming to meet the demands of the family at each phase of its trajectory, collaborating for a continuous and integral nursing care.
\end{abstract}

Descriptors: Social Support; Pediatric Nursing; Family Relations; Tracheostomy; Chronic Diseases.

\section{RESUMO}

Objetivo: compreender o apoio social de famílias de crianças traqueostomizadas. Método: estudo qualitativo que utilizou como referenciais teóricos o modelo de Apoio Social e suas Dimensões e o modelo Sistema Familiar-Doença, e cuja análise foi pautada pelo modelo Híbrido de Análise Temática. Foram entrevistadas nove famílias de crianças traqueostomizadas em acompanhamento no serviço ambulatorial de otorrinolaringologia pediátrica de um hospital público do interior do estado de São Paulo. Resultados: a experiência de apoio social peculiar a cada fase da experiência da família foi apresentada em três temas: "Saber da necessidade de traqueostomia" "Realizar a traqueostomia" e "Conviver com a traqueostomia". Considerações Finais: compreender como se dá a experiência do apoio social pode subsidiar estratégias de avaliação e intervenção, visando atender às demandas da família em cada fase de sua trajetória, colaborando para uma assistência de Enfermagem contínua e integral.

Descritores: Apoio Social; Enfermagem Pediátrica; Relações Familiares; Traqueostomia; Doença Crônica.

\section{RESUMEN}

Objetivo: Entender el apoyo social de las familias con niños traqueostomizados. Método: Estudio cualitativo en que se utilizó como marco teórico el modelo de apoyo social y sus dimensiones y el modelo sistema familiar-enfermedad, y en el análisis se utilizó el modelo híbrido de análisis temático. Se entrevistó a nueve familias con niños traqueostomizados en seguimiento en el Servicio Ambulatorio de Otorrinolaringología Pediátrica de un hospital público del interior del estado de São Paulo. Resultados: La experiencia de apoyo social específico a cada fase de la experiencia de la familia ocurre de tres maneras: "Saber de la necesidad de la traqueostomía", "Realizar la traqueotomía" y "Convivir con la traqueotomía". Consideraciones finales: El entendimiento sobre cómo ocurre la experiencia del apoyo social puede permitir que se establezcan estrategias de evaluación e intervención, para atender las demandas de la familia en cada fase de su trayectoria y colaborar con una asistencia de enfermería continua e integral.

Descriptores: Apoyo Social; Enfermería Pediátrica; Relaciones Familiares; Traqueostomía; Enfermedad Crónica. 


\section{INTRODUCTION}

Technological advances during the last decades have made it possible to increase life expectancy and the survival of children with severe health condition ${ }^{(1)}$. However, these children may become dependent on technological devices to aid and monitor their vital functions. Tracheostomy is among the devices that brings the most questions and insecurity regarding the care needed for its maintenance ${ }^{(2)}$.

Caring for a child with tracheostomy is not an isolated process, but rather it involves the whole family. It is vital to understand the meaning that the condition has for the family, how the management of a chronic condition is, how family members organize themselves and what kind of support they have. These define the behavior of the family during the treatment of the child ${ }^{(3)}$.

Changes in family dynamics can trigger behavioral changes in their members, who experience impacts on quality of life, which then reflects on relationships and family life. As a result of these tensions, an increase in the number of divorce, financial problems and overload of the main caregiver may occur. Another damaging factor is social isolation. Families with tracheostomized children tend to be socially isolated because of their many daily activities, concerns about the child's risk of pathogen exposure, and embarrassment in performing care procedures on the tracheostomized child in public ${ }^{(3-5)}$.

Families are able to find the strength to overcome this moment as they receive social support, stimulating a positive view on the future and the obstacles derived from the disease, providing the possibility of coping with all the demands, with the construction of social support networks ${ }^{(3,6)}$.

Social support has been defined as a multi-dimensional phenomenon related to the health of the individual, including the set of all resources provided by other people to the other and the totality of information that makes the individual consider himself loved and cared for, since they belong to a social network of people who can contribute to coping with problems and provide benefits to physical, mental and social health ${ }^{(7)}$.

In the last decades, there has been great interest in researching social support in several contexts, due to the positive impact on the individual's physical and emotional health. The concept was defined by different authors, among them Hans Veiel, who describes the Model of Dimensions of Social Support ${ }^{(8)}$.

The nurse must acknowledge the experience of social support of families with tracheostomized children in order to plan strategies to strengthen such families, which motivated this study.

\section{OBJECTIVE}

To understand the experience of social support of families with tracheostomized children.

\section{METHOD}

\section{Ethical aspects}

This project was appreciated by the Research Ethics Committee, receiving approval on June 21,2017 , in compliance with the norms of Resolution 466/2012 of the National Health Council ${ }^{(9)}$. Participant names have been replaced by fictitious names.

\section{Theoretical framework}

The Model of Dimensions of Social Support ${ }^{(8)}$, developed by Dr. Hans Veiel, was used to design data collection and analysis. Veiel designed a conceptual framework modeling social support into three dimensions: support type, which is divided into psychological, instrumental, support daily and during crisis; context of relations (sources) and evaluation of support. In order to conceptualize, instrumentalize and evaluate social support, Veiel's model answers the following questions: What is provided? Who provides it? How is it evaluated? The questions refer to the type of support provided, a bond present between the provider and the recipient of support and evaluation of support, respectively. The Veiel model delineates the understanding of the social support experience, facilitating the understanding of the dynamics of social support. Thus, this framework guided the data collection and interpretation. However, considering the phenomenon being studied is a chronic condition, as well as the context and the density of experiences, the best way to present the data would be relating it to each disease phase, which, in terms of social support, have very particular characteristics. For this purpose, the Family System-Illness Model was used ${ }^{(10)}$.

This model was proposed by John Rolland and Froma Walsh, and it indicates that in order to promote discussions for coping with the chronic disease, it is necessary to raise several questions, varying according to the periods of disease development and the stage of treatment of each individual. The authors divide it into three phases: crisis, chronic and terminal ${ }^{(10)}$. In the context of this research, it was relevant to consider the tracheostomy experience of the child as containing both the crisis and chronic phases.

\section{Study approach}

This is qualitative inquiry, providing adequate and substantiated subsidies, examined from the perspective of the subject itself, allowing to deepen in the subjectivity observed from the social actions and relations ${ }^{(11)}$.

\section{Study scenario}

This study was conducted at the pediatric outpatient otorhinolaryngology department of a public hospital in the inner state of São Paulo, Brazil.

\section{Data source}

Data were collected from families with tracheostomized children. Inclusion criteria were family members older than 18 years, who cared for previously healthy children before tracheostomy, and who had no other technological health devices.

\section{Data collection}

The families were invited to participate in the survey, receiving the necessary clarifications. After acceptance, the Informed Consent Form was exposed and signed by the families.

Data were collected through semi-structured interviews, and through the genogram and ecomap, which are family assessment 
instruments known for their effectiveness in collecting information about the family in clinical practice and health research ${ }^{(12)}$. Data collection took place from September 2017 to February 2018. As a criterion to define the moment for interrupting the data collection, saturation was used ${ }^{(13)}$.

The interviews were based on a guiding question: tell me how your daily routine and your family life have been since the tracheostomy in your child. The questions to follow were based on the sub-dimensions of support during crisis and daily support, according to the Model of Social Suuport ${ }^{(8)}$ Examples of these questions would be: what kind of support do you need when you have a problem with your child? What kind of support do you need in your daily child care?

Each participant was interviewed once. Nine interviews with an average duration of 25 to 30 minutes were audio recorded.

\section{Data analysis}

The data were analyzed using the hybrid thematic analysis model ${ }^{(14)}$ that combines both an inductive and a deductive approach.

The coding steps to investigate the data using this hybrid analysis model are: developing a template, which in this study was made using the Model of Dimensions of Social Support ${ }^{(8)}$; data synthesis and identification of initial themes, where in this second stage, the interviews were carefully read, and later a synthesis of the raw data allowed to draft points highlighted by the participants; the template was applied, and at this stage deductive coding was conducted, the template was applied for the recognition of significant deductive text units (based on Veiel's theoretical model); connection between codes and identification of themes, where at this stage, codes were connected and new themes emerged from this connection or were added to pre-existing ones; confirmation, where at this stage, the grouping process for previously identified themes was defined, and a thorough investigation of all previous steps by the two researchers was conducted, as recommended ${ }^{(14)}$.

\section{RESULTS}

Nine families with tracheostomized children participated in the study. All the interviewees were women, seven of them being mothers, one maternal grandmother and one paternal grandmother. Participants' ages ranged from 19 to 51 years, eight of whom presented themselves as housewives. With regard to marital situation, seven were married, however, at the moment, two did not live with their companion, and two were divorced. Tracheostomized children ranged from 40 days to 9 years, and the length of time with the tracheostomy ranged from 1 month to 4 years.

Through hybrid analysis of the data, the experience of social support was better understood and, due to its different demands and characteristics during the evolution of the child's chronic condition, it was decided to organize the data into three themes, according to the trajectory of the chronic disease in the family, described in the Family System-IIIness Model ${ }^{(10)}$, namely, two phases of crisis (knowing the need for a tracheostomy and performing the tracheostomy), and a chronic phase (living with tracheostomy).

\section{Knowing the need for a tracheostomy}

The families of this study did not expect they would have a child with tracheostomy. They are families who experienced the hospitalization of their children for days or months, who previously presented themselves in perfect health conditions. Afflicted by various pathologies that required hospitalization in intensive care units with sedation, mechanical ventilation and being restricted to the bed, children were already in a state of prolonged suffering, which also generates feelings of hopelessness, fear, uncertainties, and loss of family autonomy.

It is an experience of great distress that triggers the first family crisis in this trajectory. Knowing the need for a tracheostomy is the most difficult time faced by these families. This circumstance leads high levels of anxiety and stress, and can generate conflict and denial related to the care that the child requires.

Wow... I got despaired, because for me that was the end of the world and I did not accept it at all... for me it was just desperation, I thought... it was all over. (Maria Clara)

Reluctance to consent to the procedure is based on the loss of normality, as these families are confronted with the changes that the procedure will cause to their daily life. The lack of knowledge about tracheostomy, the risks of surgery, and the care required, how the child would live after this procedure, are also cause for many concerns.

Actually at first we were reluctant to put it on, because we thought we would never have a normal life again... I mean, the doctor came and mentioned how it would be from six months to two years! Then I said: oh, our daughter! It will be the end, we won't do anything else in life, we will live just to take care of her. (Wilma)

The demands that the families present at this stage are mainly of a psychological and instrumental character, and the support received is punctual, characterized as support during crisis. At this stage, they are willing to accept all the support provided.

I was willing to accept whatever would help me. At the time of Luana's hospitalization, I had no psychologist support, I wish I had a follow up. (Janaína)

Faced with such shock and unknown, families look around and seek support. Some are ready to allow to receive such help from nursing professionals, since they received encouragement and motivation from them, which leads to greater confidence about the many future concerns about the care of the tracheostomized child.

[...] in the hospital, there were a lot of people on the nursing team to help. (Mariana)

The demand for information is the most significant at this stage of the family journey. In this sense, they acquire clarifications from the medical team regarding the reasons for surgical intervention and its implications in the child's health.

The doctors gave a lot of support, instructed well, they talked about everything that was happening with Leandro. When we had doubts, they explained again. (Wilma) 
Regarding the support during crisis that they received from their families, some report that they enjoyed the company of some relatives. There is a tendency of these families to join forces within their family system.

So the one who helps me is just my husband. Right here in the hospital, no other people wanted to come and be with her, just my husband. (Natália)

On the other hand, other families felt alone, because they could not enjoy the support of the rest of the family, of the spouse, being certain of their isolation in any circumstance, which increased the overload of individual members of the family.

I was alone, because her father is in jail, so I had no help from anyone. My mother has depression and at the time she was under treatment and could not help me. (Francisca)

Thus, looking at the challenges imposed by knowing the need for the child's tracheostomy, it is understood that, faced with the demand for information and emotional support in the middle of this phase, the kind of support received is that of support during crisis, and the support sources were the health care team that cares for the child as well as the rest of the family. The assessment of support influences how the family experiences this phase, and can give confidence and help decide autonomously, but also increasing uncertainties and feelings of isolation.

\section{Performing the tracheostomy}

With no time to adjust to the need to perform the tracheostomy, the family embarks on a second abrupt and sudden change, triggered by the first: performing the tracheostomy. The families understand the procedure as threatening and very dangerous, they fear the possibility of death of the child, since they consider them very fragile and debilitated to undergo surgery. This fear regarding the surgical procedure necessary for insertion of the tracheostomy causes insecurity and other feelings that haunt families.

I was terribly afraid she wouldn't survive the surgery to get the tracheostomy because she had to have a general anesthetic and she's very young, so I was scared. (Janaína)

As the families waited for the procedure, they immersed themselves in feelings of anxiety, sadness and uncertainty. This moment has been marked in the lives of these families, so that many of them cannot contain their tears and emotions when remembering it.

I had a panic attack, [the mother gets very emotional], while they were doing the tracheostomy in Emanuelle, I was at the hospital emergency being taken care of. (Francisca)

When performing the tracheostomy, the demands of the family relate to the new misadjustment that occurs, so often followed by the previous misadjustment, in the experience of the illness. In order to meet the several demands of care and adjustment, the family seeks instrumental and psychological support in the midst of the new crisis that they experience. Many of the activities needed to meet and keep pace with this period require resources beyond what previous support sources could offer.

In order to resolve doubts and teach the necessary care to maintain tracheostomy, the health team introduces the family to the care training process. Some families suffered with this reality and the pressure caused by the compulsion to learn how to perform daily care, others had not yet won against the challenge in accepting that their child had tracheostomy.

My fear was to do the aspiration, my fear was this... something happening to her, that was my fear. (Natália)

The doctors said that I had to accept it... that for me, accepting it would be easier to care for her. I said: I accept in part... but to say I accepted, I didn't, it is affecting me too much, I cry a lot. (Maria Clara)

The families in this study report changes in family roles as a result of the tracheostomy and its resulting demands. From the need of tracheostomy to realization, attention to food, sanitation and activities related to school or day care are repressed. When there are other children in the family, this increases wear and overload, especially in mothers and grandmothers.

Thus, the support received was of an instrumental and psychological nature and comes, essentially, from the family itself. Relatives such as mothers and spouses have provided material demands related to caring for other children. Other members, such as in-laws and uncles, promoted domestic chores. Psychological support was provided through the daily connections of some of the children's grandparents, who, although far away, expressed their interest and concern about the state of health of the grandchild and the family, showing affection, companionship, and being ready to listen to their complaints and restlessness.

Everything changed because I had another child, and he was going to school, so we had to completely change the rhythm. My husband already had to go a little more ahead for my son. [...] and I have a sister-in-law who helped me [...] she visited me and helped wash some clothes, made some food. (Natália)

The families valued all the support received at this phase. The main support sources considered were professionals, and the rest of the family. They considered essential the psychological and instrumental support they received from their spouse and/ or relatives, such as mother, son, sister-in-law, mother-in-law, paternal grandmother and uncles.

The support of my mother affects me on practically everything. (Neide)

However, for some families, needs are not always fulfilled, and limitations and restrictions on the support received by families can be observed.

The support makes it easier, but like... they [sister-in-law and mother-in-law] are also afraid, right. They are not professionals, I don't feel safe... I feel a bit safe about having people on my side, but not entirely. (Janaína) 


\section{Living with tracheostomy}

This new moment is characterized as the chronic phase of the experience ${ }^{(10)}$, since it represents greater stability of the child's condition and encompasses routine modifications, difficulties in tracheostomy care, occasional episodes of health crises, and the return to social activities. In order to meet the demands and adjustments of this stage of the trajectory, the families need daily support, in addition to support in occasional moments of crisis that may arise.

Tracheostomized children have many peculiar demands for care, which requires family members to have determination, periodicity and to be vigilant. The maintenance and care of the device is vital and integral, making it necessary to aspire the child several times during the night, for instance, making it impossible for the working family to have a quality night's sleep. Allied to this activity, there is a need to be vigilant and sensitive to any signs of discomfort of the child, since crying is inaudible, increasing the suffering of families.

\begin{abstract}
Ah! It's very difficult... because I do not sleep, you have to do aspiration at night. I'm afraid of sleeping and not being able to listen to her and she'll end up filled with secretion, that's my biggest fear. (Janaína)
\end{abstract}

Family social life also undergoes much transformation. Unlike the time without tracheostomy, activities that once seemed simple are now obstacles that families must face when living with the condition. The many artifacts required for the care of the child and the frequency with which they are carried out in a stable place with access to the electricity grid prevent them from being in a bus for long periods, which is usually the only means of transportation some families have to take themselves to medical appointments. As a result of the impediments encountered by these families to leave their homes with the tracheostomized child, many stop engaging into outside activities, making it impossible for leisure activities and family entertainment to occur. In this way, some families feel that the child's condition has permanently transformed their family environment, causing isolation and social separation.

It is a life of isolation and total prejudice... even his father, after he put the tracheostomy he stopped visiting. (Wilma)

[...] by bus it's 2 hours from the hospital, there is no way to come with her alone by bus to the consultations, because there is no way to do aspiration on her in a bus. (Francisca)

Tracheostomized children also move away from their activities. The long hospitalization time, the need for insertion of the device, the intercurrences when living with tracheostomy and the lack of a tutor in the school unit trained to perform care with the device lead to great insecurity in the families with regard to allowing the child to return to school or day care. Sometimes, it is necessary to resort to judicial orders in order to guarantee the presence of a professional specialized in this sort of care.

[...] Alice doesn't go to school because I don't feel safe about it, and the network does not make me any more secure to leave her without anyone except a tutor, Ineed this because if she takes the tracheostomy out, someone has to put it in. (Karina)
The families faced various challenges to perform some daily care activities with the tracheostomized child, such as exchange of tracheostomy fixation and bath. In the first few weeks, these were the activities that caused the most anxiety, due to the possibility of the cannula being withdrawed by the child during the exchange, as well as the inflow of water into the cannula. Some families did not feel prepared and able to carry them out without support.

[...] so, in the first few weeks that I went home to switch the tracheostomy lace, I needed someone to hold, so I had to pay a nurse to go home and change it for me since I was afraid, I didn't know, I cried, I thought I would let it go. (Francisca)

The child's illness also has repercussions on the financial aspect of the family, with the accumulation and increase of many expenses related to transportation for treatment. There are also additional expenses with electric bills, due to the various daily aspirations with the materials to maintain the device due to the limited quantity made available to each family by health units, with medicine and specific foods not found in the health network.

Even with the child's tracheostomy requiring new modifications after a few months, some families consider they do not cause great problems in their routine, and feel able to gradually promote family entertainment activities, make new plans, studies and, within this dynamic, they perceive they can redefine the concept of normality in their lives, re-defining a balance between intra- and extra-family relationships, as well as between the family's daily activities and tracheostomy care.

If I have to go to the mall, this won't stop me from going because she also has to get some resistance, so I go and take her. If I have to go to the market, some time before I wouldn't take her, today I do take her, because she doesn't use the oxygen anymore so I don't have to keep taking the aspirator with me anymore. (Mariana)

The families evaluated the support during the chronic phase as something of great importance and that the absence of it would make the trajectory more painful and conflicting, however, they would like it to be continuous and regular.

If my sister did not help me I don't know what would have happened... but I still feel I need a lot of help [...]. Oh, my hair, I can't do my hair, I can't do my nails, I can't do anything, I can't go to the market buy something. (Francisca)

\section{DISCUSSION}

The families in this study describe feelings of sadness, uncertainty, fear, denial and loss of autonomy as they go through each phase of this trajectory, starting with when they receive the diagnosis until they reach the stage of living with the disease. The literature has already described a mix of feelings that families with children who have chronic diseases face by being informed about the disease and its treatment, as well as some of their main demands, such the demand for information, as found in this study ${ }^{(15)}$.

There are many doubts and questions originated from the diagnosis and treatment of the disease, some families had no knowledge about the child's illness, and clarifications about appropriate interventions 
to improve the condition were necessary. In addition to all the tasks related to the tracheostomized child and maintenance of the family unit, other anxieties arise, such as those related to the requirement of care suitability for discharge. There is a need for training and planning for the moment of discharge, but the lack of success in preparing the families brings back the same fears and instabilities, concerning the possibility of some kind of intercurrence or malpractice occurring in the domestic environment.

However, the families claim they receive informational support at these times, but that it occurs quickly and punctually, and that doing so more slowly and gradually is better indicated in various contexts. Studies have pointed out the importance of considering the rhythm of processing and assimilation of content by the families regarding the diagnosis as reconciled with the course of treatment, since the onset is more difficult and arduous, and the obstacle in appropriating a large amount of information accumulated is mentioned ${ }^{(15-17)}$.

Even with discharge training for the child, there is still hesitation in conducting care without supervision of a professional. The literature has shown the importance of structuring training programs for families of children with chronic and technologydependent diseases, since gaps in the discharge procedure are indicated as triggers for hospital readmissions, medication errors, discouragement and increased levels of family stress ${ }^{(18-19)}$.

Given this context, a recent program to support families in the context of pediatric oncology deserves attention. With the proposal to improve the knowledge and skills of families with children recently diagnosed with cancer, it reinforces the importance of initiating discharge training from the very moment of diagnosis. The program is based on the main difficulties related to hospital discharge in various contexts of chronic diseases and traces a "return home route", a path that is progressed according to the fulfillment of certain steps, called Road to Home ${ }^{(20)}$.

When living with tracheostomy, the challenges continue in childcare activities, in routine tasks of the family, with the increase of expenses and work overload. The other children lack attention and care, home maintenance activities are intense, there are intercurrences, extrapolated monthly expenses, scheduled and emergency consultations, as well as recurrent sleepless nights, all of these factors triggered by the worsening in health condition, having many implications for family life. Social isolation is also perceived as a consequence of these factors, requiring practical and informational support to organize and manage the demands that come with it. These and other changes in family routines were also seen in other studies of families with children dependent on technology ${ }^{(21-23)}$.

Intercurrence moments are disappointing and frightening, some families think that regardless of time and training they will never know how to handle the situation. An international study presents some interventions to prepare families to manage possible intercurrences or clinical emergencies that may arise in the stage of living with the child's tracheostomy. High fidelity simulation has been used as teaching methodology, including audiovisual and printed material, training for cardiopulmonary resuscitation practices and scenarios that reproduce emergencies related to tracheostomy ${ }^{(24)}$.

An alternative also suggested by families that could support them at such times is the use of virtual information sharing tools, such as social media, blogs and websites. The internet has increasingly been used by families of children with various chronic conditions as an essential means to assist in the care of these children. It can also be a place where families can exchange information on therapeutic alternatives and diagnoses, thus increasing the understanding of family members and contributing to reduce their feelings of insecurity in dealing with some situation related to the child's health. It is possible to find specific content for families with children who have tracheostomy, namely explanatory videos and care protocols, providing autonomy to families with regard to problem solving and an instantaneous exchange of information and experiences. Therefore, it is essential to add the virtual universe as a tool to meet the demands of families affected by the chronicity of the child, ensuring credibility, truthfulness and consistency of data content ${ }^{(25-27)}$.

Another demand strongly indicated by the families of this study is related to the disconnection with social life. The technological dependence of the child creates social barriers due to the many equipments necessary for the child's care, the frequency of carrying them out at a stable place, and access to the electricity grid, the vulnerability of the child's health condition, the difficulty of transportation and the lack of support. All these points contribute to the isolation of families from social life $\mathrm{e}^{(23,28)}$.

Obstacles to the return of school activities are in line with the lack of a tracheostomy-trained guardian, in spite of this raising insecurity in the families, many seeking support in educational institutions, however, almost all children were not admitted, increasing the challenges for the return of mothers and grandmothers to paid activities, since they were prevented from continuing the exercise of their regular functions. As a consequence, children involuntarily isolate themselves, being unable to participate in activities aimed towards social and cognitive development, contributing to generate negative changes in the behavior of older tracheostomized children, making the search for psychological support necessary.

\section{Study limitations}

The impossibility of interviewing male participants is considered a limitation of this study. Two out of the nine families interviewed had their father present at the time of the approach, but they did not want to participate in the interview.

\section{Contributions to the field of Nursing}

The knowledge of families with tracheostomized children and the search for support structures that help them adapt and redefine normality can lead to initiatives in the nursing team that can help these families.

Thus, the implementation of a structured program to prevent families from returning home with knowledge gaps should be observed by the nursing team, thus avoiding insecurity when conducting care, recurrent hospitalizations, risks of impairment in the child's health condition, and emotional overload in the family, in such a way that, little by little, they can redefine a new way of working and achieving balance.

Other contributions indicate the importance of intervention in the management and conviviality of families with tracheostomized children, creating new ways to offer the necessary and adequate social support while considering the particularities of 
each family. For instance, promoting social interaction activities with other families who are going through the same experience by creating support groups to reduce family social isolation and sharing strategies and skills. It also points to the urgency of thinking about the virtual environment as a window of opportunity for the nurse's work, who must be present and take advantage of this space and all its possibilities for exchange, interaction and support offer that it allows.

\section{FINAL CONSIDERATIONS}

The models adopted allowed to unveil the understanding of the social support of these families throughout the trajectory of the disease. The use of two associated models was a challenging choice, but it generated a much clearer and deeper understanding of how particular the family demands are at each stage of the disease, as well as the possibilities and offers of social support. It was possible to perceive that the right of the tracheostomized child to return to school activities in a safe way has been neglected due to the lack of qualified guardian. This reality leads to child isolation and can also trigger losses in their social development. It is known that health professionals are in charge of orientation on the subject, as well as advancing in this discussion at a public policy level, to support and encourage families to seek the guarantee to these rights.

\section{FUNDING}

Scholarship awarded by the Coordination for the Improvement of Higher Education Personnel (Capes).

\section{REFERENCES}

1. Cohen E, Berry JG, Camacho X, Anderson G, Wodchis W, Guttmann A. Patterns and costs of health care use of children with medical complexity. Pediatrics. 2012;130(6):e1463-70. doi: 10.1542/peds.2012-0175

2. Guerini IC, Cordeiro PKS, Osta SZ, Ribeiro EM. Relatives' perception regarding the stressors resulting from the care demands of technologydependent children and adolescents. Texto Context Enferm. 2012;21(2):348-55. doi: 10.1590/S0104-07072012000200012

3. Mendes-Castillo AMC. Manejo familiar no transplante hepático da criança [tese]. São Paulo: Universidade de São Paulo; 2011. doi: 10.11606/T.7.2011.tde-16052011-103823

4. Silva MEA, Moura FM, Albuquerque TM, Reichert APS, Collet N. Network and social support in children with chronic diseases: understanding the child's perception. Texto Contexto Enferm. 2017;26(1):e6980015. doi: 10.1590/0104-07072017006980015

5. Pedro ICS, Rocha SMM, Nascimento LC. Social support and social network in family nursing: reviewing concepts. Rev Latino-Am Enfermagem. 2008;16(2):324-7. Doi: 10.1590/S0104-11692008000200024

6. Nóbrega VM, Collet N, Silva KL, Coutinho SED. Rede e apoio social das famílias de crianças em condição crônica. Rev Eletr Enferm. 2010;12(3):431-40. doi: 10.5216/ree.v12i3.7566

7. Vaux A. Social support: theory, research, and intervention. New York: Praeger Publishers; 1988.

8. Veiel HO. Dimensions of social support: a conceptual framework for research. Soc Psychiatry [Internet]. 1985 [cited 2017 Mar 15];20(4):15662. Available from: https://link.springer.com/article/10.1007/BF00583293

9. Ministério da Saúde (BR). Resolução n 466, de 12 de dezembro de 2012. Aprova as diretrizes e normas regulamentadoras de pesquisas envolvendo seres humanos e revoga as Resoluções CNS nos. 196/96, 303/2000 e 404/2008 [Internet]. Brasília: Ministério da Saúde; 2012 [cited 2017 Mar 15]. Available from: http://bvsms.saude.gov.br/bvs/saudelegis/cns/2013/res0466_12_12_2012.html

10. Rolland JS, Walsh F. Facilitating family resilience with childhood illness and disability. Curr Opin Pediatr. 2006;18(5):527-38. doi: 10.1097/01. mop.0000245354.83454.68

11. Ludke M, André MEDA. Pesquisa em educação: abordagens qualitativas. 2a ed. Rio de Janeiro: EPU; 2017.

12. Wright LM, Leahey M. Enfermeiras e famílias: guia para avaliação e intervenção na família. 5a ed. São Paulo: Roca; 2012.

13. Tarozzi M. O que é a grounded theory? Metodologia de pesquisa e de teoria fundamentada nos dados. Petrópolis: Vozes; 2011.

14. Fereday J, Muir-Cochrane E. Demonstrating rigor using thematic analysis: a hybrid approach of inductive and deductive coding and theme development. Int J Qualit Methods. 2006;5(1):80-92. doi: 10.1177/160940690600500107

15. Rodgers CC, Stegenga K, Withycombe JS, Sachse K, Kelly KP. Processing information after a child's cancer diagnosis: how parents learn: a report from the Children's Oncology Group. J Pediatr Oncol Nurs. 2016;33(6):447-59. doi: 10.1177/1043454216668825

16. Kornburger C, Gibson C, Sadowski S, Maletta K, Klingbeil C. Using "teach-back" to promote a safe transition from hospital to home: an evidence-based approach to improving the discharge process. J Pediatr Nurs. 2013;28(3):282-91. doi: 10.1016/j.pedn.2012.10.007

17. Siqueira CSS, Reis AT, Pacheco STA. Models of care for families of technology-dependent children in a hospital context. Rev Enferm UERJ. 2017;25:e27529. doi: 10.12957/reuerj.2017.27529

18. Martins H, Oliveira IS, Silveira T. A criança com traqueostomia e a sua família face à alta clínica. Salutis Scientia [Internet]. 2011 [cited 2018 Aug 10];3:33-40. Available from: http://www.salutisscientia.esscvp.eu/Site/Artigo.aspx?artigoid=30555

19. Tolomeo CT, Major NE, Szondy MV, Bazzy-Asaad A. Standardizing care and parental training to improve training duration, referral frequency, 
and length of stay: our quality improvement project experience. J Pediatr Nurs. 2017;32:72-9. doi: 10.1016/j.pedn.2016.10.004

20. Wilson Smith MG, Sachse K, Perry MT. Road to Home Program: a performance improvement initiative to increase family and nurse satisfaction with the discharge education process for newly diagnosed pediatric oncology patients. J Pediatr Oncol Nurs. 2018;35(5):368-74. doi: $10.1177 / 1043454218767872$

21. Lindahl B, Lindblad BM. Being the parent of a ventilator-assisted child: perceptions of the family-health care provider relationship when care is offered in the family home. J Fam Nurs. 2013;19(4):489-508. doi: 10.1177/1074840713506786

22. Lindahl B, Lindblad BM. Family members' experiences of everyday life when a child is dependent on a ventilator: a metasynthesis study. J Fam Nurs. 2011;17(2):241-69. doi: 10.1177/1074840711405392

23. Joseph RA. Tracheostomy in infants: patient education for home care. Neonatal Netw. 2011;30(4):231-42. doi: 10.1891/0730-0832.30.4.231

24. Thrasher J, Thrasher J, Ventre KM, Martin SE, Dawson J, Cox R, et al. Hospital to home: a quality improvement initiative to implement high-fidelity simulation training for caregivers of children requiring long-term mechanical ventilation. J Pediatr Nurs. 2018;38:114-21. doi: 10.1016/j.pedn.2017.08.028

25. Mazza VA, Lima VF, Carvalho AKS, Weissheimer G, Soares LG. Online information as support to the families of children and adolescents with chronic disease. Rev Gaúcha Enferm. 2017;38(1):e63475. doi: 10.1590/1983-1447.2017.01.63475

26. Huby K, Swallow V, Smith T, Carolan I. Children and young people's views on access to a web-based application to support personal management of long-term conditions: a qualitative study. Child Care Health Dev. 2017;43(1):126-32. doi: 10.1111/cch.12394

27. Armstrong AW, Johnson MA, Lin S, Maverakis E, Fazel N, Liu FT. Patient-centered, direct access online care for management of atopic dermatitis. JAMA Dermatol. 2015;151(2):154-60. doi: 10.1001/jamadermatol.2014.2299

28. Okido ACC, Zago MMF, Lima RAG. Care for technology dependent children and their relationship with the health care systems. Rev LatinoAm Enfermagem. 2015;23(2):291-8. doi: 10.1590/0104-1169.0258.2554 